(C) 2014

\author{
Семіренко В. В., аспірант
}

(науковий керівник - доктор ветеринарних наук Б. П. Киричко)

Полтавська державна аграрна академія

\title{
ЗДОРОВІ КІНЦІВКИ - ОСНОВА ВИСОКОЇ ПРОДУКТИВНОСТІ СВИНЕЙ
}

\section{Рецензент - кандидат ветеринарних наук Р. В. Передера}

У статті йдеться про важливість функиіонального стану кіниівок у свиней. Детально говориться про діагностичне дослідження ратиць та вплив факторів ризику виникнення кульгавості. Слід зазначити, щзо порушення функиії опорно-рухової системи свиней істотно впливає на їх продуктивність. У тексті подається иінна інформація про особливості діагностики ратиць у свиней. Головна мета автора - проводити правильну діагностику й профілактику хвороб функиіонального стану кіниівок $i$ ратицьь. Стаття стане в нагоді лікарям ветеринарної медицини, науковим співробітникам у подальших дослідженнях у галузі свинарства.

Ключові слова: свині, кінцівки, діагностика, догляд, профілактика, продуктивність.

Постановка проблеми. Хвороби ратиць у свиней часто залишаються непоміченими і перетворюються на хронічну кульгавість тому, що сучасна практика штучного запліднення не вимагає відсутності дефектів опорно-рухового апарату свиноматки. Ситуація тільки погіршується через те, що в умовах інтенсивного промислового свинарства персонал недостатньо освічений та невмотивований, аби боротися з кульгавістю [4].

Аналіз основних досліджень і публікацій, у яких започатковано розв'язання проблеми. Хвороби ратиць мають поліфакторну проблему виникнення. Окремі фактори ризику згадуються у працях закордонних і вітчизняних науковців (В. М. Авроров, П. П. Герцен, І. С. Поваженко, К. О. Попов, Є. М. Глазьєв, Sarel van Amstel, Tomas Doherty). Останнім часом проблема хвороб кінцівок і ратиць у свиней набула детального вивчення (через виявлення інфекційних збудників, зниження економічних аспектів, зміни умов утримання).

Згідно з результатами досліджень, проведених науковцями університету штату Айова (ISU) на цілій низці товарних свиноферм, понад $84 \%$ свиноматок мають пошкодження принаймні однієї ратиці [4]. За даними дослідження Sarel van Amstel в університеті Теннесі (2013 рік), копитний ріг у свиней за місяць росте на 5,1-6,3 мм й стирається залежно від маси тіла тварини [11].
Під час лікування кульгавості у свиней в якості комплексної терапії російськими вченими (К. О. Попов, Є. М. Глазьєв, С. А. Ширков, С. М. Юрченко, С. А. Кукушкін) проводилось порівняння дії препаратів «Мелоксікам» та «Кетопрофен». За результатами досліджень «Мелоксікам» ефективний на $81 \%$, ніж при використанні «Кетопрофену», де позитивний ефект досягався тільки у 58 \% дослідженої групи [7].

Гвендолін Джонс проводила зміну раціону 3 додаванням фітази, що позитивно впливає на функціонування опорно-рухового апарату й сприяє підвищенню продуктивності свиней [1].

Мета дослідження: узагальнення й систематизація літературних даних щодо діагностики та профілактики хвороб, а також функціонального стану кінцівок і ратиць у свиней.

Завдання дослідження: з'ясувати особливості діагностики, лікування та профілактики хвороб ратиць у свиней, а також фактори ризику впливають на продуктивність та функціональний стан кінцівок і ратиць у свиней.

Методи і методики дослідження. Під час дослідження використовувалися методи аналізу, статистики, порівнянням літературних джерел вітчизняних і зарубіжних науковців стосовно даної теми.

Результати дослідження. Для вивчення стану ратиць у свиней застосовують загальні методи клінічного дослідження: огляд, пальпацію, перкусію.

Огляд ратиць. Спочатку ратицю очищають від бруду, за необхідності ії обмивають водою або застосовують ванну для ніг, проводять розчистку ратиці. За допомогою огляду визначають характер опирання кінцівкою, форму і стан окремих ділянок копитець - вінчика, стінки, підошви i м'якуша. У разі виявлення змін форми копитного рогу необхідно встановити причину деформації (неправильна постановка кінцівок, обламування копитного рогу, захворювання зв'язок) [6].

За характером опирання кінцівкою судять про локалізацію патологічного процесу в ратиці. Наприклад, у випадку хвороб, які локалізуються в задніх ділянках ратиці (колоті рани в області 


\section{СТОРІНКА МОЛОДОГО ВЧЕНОГО}

м'якуша, запальні процеси в сухожиллі глибокого згинача пальців, у пальцевому м'якуші), тварина спирається зачіпною частиною ратиці. У випадку ураження передніх і бокових ділянок ратиць (ревматичне запалення) тварина спирається П’ятковими частинами ратиць, виставляючи кінцівки вперед [8].

Під час огляду вінчика звертають увагу, чи немає на ньому ран, виразок, нориць і набряків. Особливо ретельно оглядають шкіру в ділянці міжкопитцевої щілини. Набряк вінчика може бути обмеженим або ж дифузним чи розлитим по всій його окружності (дифузна флегмона, гнійне запалення копитного суглоба). Поглиблення в ділянці вінчика свідчить про зміщення копитної кістки (хронічне ревматичне запалення ратиць) [5].

Під час огляду рогової стінки звертають увагу на іiі нахил, стан поверхні, характер кільчастості, цілісність рогу. На копитній стінці можуть спостерігатися наступні відхилення від норми: тріщини, розколи, кіркоподібна шорсткість стінки (хронічне запалення основи шкіри облямівки), рогові нарости (хронічне запалення основи шкіри вінця), патологічна кільчастість (кільця, зближені в зачепі й розходяться до п'яткових стінок - у разі хронічного ревматичного запалення ратиць), обламування країв рогової стінки [6].

Особливо ретельно оглядають підошву ратиці. Звертають увагу на форму й увігнутість підошви (пласке, повне, стисле копитце), стан білої лінії (порожня стінка, роговий стовпчик), колір рогу підошви (червоні, жовті плями при ударах), на наявність сторонніх тіл. На м'якуші оглядом виявляють рани, відшарування рогу у випадку гнійного пододерматиту, флегмонозного набряку, асиметрії м'якушів і їх зміщення [8].

3 метою отримання більш об'єктивних даних про ступінь деформації копитець, про розміри ран та інших пошкоджень на різних стадіях патологічного процесу іноді вимірюють копитний ріг за допомогою тасьми, розділеної на сантиметри і міліметри, або циркуля (Sarel van Amstel et al., 2010) [11].

Пальпацією визначають температуру і чутливість копитець. Місцеву температуру в копитцях досліджують шляхом прикладання долоні або тильної сторони кисті руки до одних і тих же ділянок здорової й ураженої ратиці. Підвищення температури спостерігається у випадку гострих запальних захворюваннях ратиць (гострому ревматичному запаленні, пододерматиті, артриті копитного суглоба тощо), а зниження - під час обширних некрозів основи шкіри ратиці й від- шаруванні рогової стінки [6].

Перкусію копитного рогу проводять обушком перкусійного молотка або бічними поверхнями пробних щипців. Спочатку короткими уривчастими ударами вистукують п'яточні й бічні стінки, а потім підошву. Перкусію слід проводити на піднятій кінцівці, щоб виключити резонансні перешкоди. Перкусією встановлюють локалізацію патологічного вогнища (по больовій реакціiі), а іноді і його характер (роговий стовпчик, порожня стінка) [5].

Фактори ризику кульавості: умови утримання, тип підлоги, генетика, раціон годівлі.

Порушення функцій опорно-рухової системи та кульгавість пов'язані зі значною кількістю захворювань різної етіології. Більшість пошкоджень ратиць можна поділити на три основні категорії: запалення, травми (включаючи механічні) та погіршення якості рогової тканини. Найбільшої уваги заслуговують травми рогової стінки ратиці або дерми. Реакцією організму на таке ушкодження є гостре запалення, що проявляється у вертикальних і горизонтальних тріщинах зовнішнього рогового шару ратиці, виразках підошви та п'яти, пошкодженнях і відшаруваннях білої лінії [4].

Якщо причиною кульгавості $€$ інфекційне захворювання (наприклад, поліартрит), то рекомендована терапія 3 використанням антибактеріальних препаратів (Nielsen E.O. et al., 2001) [10]. У тому випадку, якщо причиною появи даних клінічних ознак стає м'язова слабкість, остеохондроз, то терапію можна проводити із застосуванням кортикостероїдів. Однак, застосування кортикостероїдів обмежене через те, що вони викликають імуносупресію, особливо під час проведення вакцинації та в період лактації. Крім того було встановлено, що введення кортикостероїдів у період лактації негативно впливає на молочність свиноматок і знижує темпи росту поросят-сисунів (Garcia M.C. et al., 1980) [9]. У зв'язку з цим у терапії болю і запалення, включаючи порушення опорно-рухової системи, MМА та ін. найбільш широкого використання отримали нестероїдні протизапальні засоби (НПЗ3) [7].

Травми копитець особливо поширені в промислових комплексах, де тварини утримуються на решітчастих і щілинних підлогах із поганою якістю матеріалу, з якого виготовляють решітки, і невідповідністю розмірів і форм щілин стандарту. Зазвичай використовують суцільні бетонні підлоги без підстилки, а також дерев'яні й металеві. Поверхня бетонних підлог - груба, 


\section{СТОРІНКА МОЛОДОГО ВЧЕНОГО}

нерівна, з вибоїнами. У процесі експлуатації бетон швидко руйнується, особливо на стиках, якими закриті гноєприбиральні транспортери. У разі утримання тварин на таких підлогах виникають удари основи шкіри м'якуша, підошви, поранення м'яких тканин, а також надмірно стирається копитцевий ріг [8].

Під час утримання на бетонних підлогах часто уражуються м'якуші пальців. На них 3'являються червоні або вишнево-червоні плями (крововиливи), які $є$ болючими й набряклими. Поступово розвивається флегмона, що упродовж 3-5 днів абсцедує і самовільно розкривається. Кульгавість, значна до розтину, помітно слабшає. Якщо ж кульавість і виділення гною тривають значний відрізок часу, це означає, що виникло ускладнення (гнійний артрит). Щоб цього не сталося, потрібно розкрити флегмонозне вогнище своєчасно. Характер первинної травми кінцівок свиней, які утримуються на решітчастих та щілинних підлогах, різноманітний. Частіше бувають садна i рани на вінчику, а також утиснення одного 3 копитець у щілини між балками [5].

Основною причиною схильності до захворювань тварин, на думку В. М. Авророва зі співавт. (1985, 1989), є гіподинамія, що призводить до порушень обмінних процесів в організмі, зменшення апетиту і засвоєння поживних речовин із корму, погіршення м'язової рецепції, недостатній приріст ваги й ожиріння, погіршення серцево-судинної діяльності, порушення репродуктивної функції, розвиток дистрофічних процесів у кістково-опорному апараті, копитному розі, що супроводжуються швидким його зносом [8].

Спостерігаються також паралічі, переломи кісток, розтягнення i розриви сухожилковозв'язкового апарату, забої, садна, рани м'яких тканин копитець, які при інфікуванні ускладнюються гнійними пододерматитами. У результаті хворі тварини приймають вимушене положення, часто переступають кінцівками, підводять їх під тулуб, кульгають, відстають у рості, втрачають вгодованість. Відсутність моціону, нерегулярне розчищення та обрізка копитного рогу зумовлює порушення механізму його росту й призводить до деформації ратиць [3].

Щоб підтримувати міцність кісток, у раціоні поросної свиноматки має бути відповідний вміст кальцію та фосфору. Результати досліджень підтвердили, що помірний дефіцит цих елементів у кормі спричиняє нижчі темпи росту та продуктивності, але не кульавість. Проблеми 3 кінцівками виникають тоді, коли нестача кальцію та фосфору справді катастрофічна, причому просте збільшення частки цих мікроелементів у раціоні навряд чи зарадить проблемі [4].

Важливо, щоб кальцій та фосфор у раціонах свиноматок були правильно збалансованими. Забагато кальцію може заважати засвоєнню фосфору. Якщо ж уміст кальцію занизький, порушується збереження фосфору в кістках. Оптимальне співвідношення цих елементів 3:1 [2].

Під час поросності свиноматці треба дати змогу накопичити достатню кількість кальцію та фосфору в кістках, аби добре підготуватися до їх посиленої мобілізації впродовж підсисного періоду. Щоб сприяти цьому, до раціону свиноматок додають фітазу. В результаті нещодавно проведених досліджень учені з'ясували, що додатковий магній у кормах свиноматок також сприяє накопиченню кальцію в кістках [1].

За групового утримання ратиці свиноматок нерідко зазнають механічного травмування, однак такі пошкодження можуть бути і вторинними - як результат деформації суглобів чи кінцівок, викликаних згаданою вище незбалансованістю мінералів у раціонах. Так, до травм ратиць може призводити і дефіцит біотину (вітаміну В). Тому для утримуваних у групах свиноматок рекомендують збільшувати вміст біотину в раціонах до 400 мкг/кг. Серед інших мінералів, що відіграють важливу роль у здоров'ї ратиць, - купрум, цинк, марганець та кобальт [5].

Догляд за ратицями. У свиноматок і кнурівплідників розчистку ратиць слід проводити 2-3 рази на рік у стоячому положенні, фіксуючи петлею за верхню щелепу або в лежачому положенні. Використовують шліфувальну машину iз грубим шліфувальним диском, щипці для обрізання та гострий ніж для коригуючого розчищення пошкоджень. Ріг із боку підошви видаляють вкрай обережно; потрібно пам'ятати, що 3 боку підошви між м'якушем і власне копитною підошвою знаходиться поглиблення із живим рогом. Після розчищення підошви видаляють ріг підошовного краю рогової стінки до рівня підошви [5].

Профілактика захворювань ратиць повинна реалізовуватися в напрямі створення нормальних умов для росту копитного рогу та попередження різних механічних ушкоджень ратиць. Формування комплексів повинно здійснюватися серед тварин, які мають правильну постановку кінцівок і форму ратиць [8].

Нi в кого не викликає сумніву доцільність розчищення ратиць, але не всі приділяють цьому належну увагу. Розчищення ратиць повинно бути включене до загальної системи профілактики 


\section{СТОРІНКА МОЛОДОГО ВЧЕНОГО}

незаразних хвороб або до плану ветеринарносанітарних заходів. Для роботи за доглядом ратиць у свиней доцільно залучати робітників за сумісництвом або у великих господарських об’єднаннях створювати спеціальні бригади [5].

Висновок. Система профілактичних заходів за хвороби ратиць у свиней повинна будуватися 3 урахуванням стану тварин, матеріальнотехнічних та економічних можливостей під час будівництва й обладнання приміщень. Утриманню свиней у промислових комплексах необхідно висувати більш високі вимоги до функціональ-

\section{БІБЛІОГРАФІЯ}

1. Гвендолін Джсон. Фітаза в раціонах продуктивних свиноматок / Г. Джонс // Ветеринарна практика. - 2013. - №10. - С. 32-34.

2. Дженс-Ерік Зеррана. Вплив годівлі в лактаційний період на подальшу продуктивність свиноматок / Дженс-Ерік Зеррана // Ветеринарна практика. - 2014. - №6. - С. 38-39.

3. Кульгавість спричиняє збитки [Електронний ресурс] // Ветеринарна практика - 2013. - №8. С. 20-22. - Режим доступу : milkua.info.

4. Обережно - кульгавість [Електронний ресурс] // Ветеринарна практика. - 2013. - №8. С. 28-31. - Режим доступу : pigua.info.

5. Молоканов В. А. Болезни копытец сельскохозяйственных животных / В. А. Молоканов, Б. С. Семёнов, К. М. Камсаев. - Челябинск, 2003. $171 \mathrm{c}$.

6. Поваженко И. Е. Болезни конечностей: болезни копыт и копытец / И.Е. Поваженко, В. Б. Борисевич. - К. : Урожай, 1987. - 208 с.

7. Попов K. O. Терапия хромоты у свиней с использованием нестероидных противовоспали- ного стану кінцівок і ратиць. Потрібно проводити ортопедичну диспансеризацію, виявляти різні пошкодження ратиць і надавати ефективну лікувальну допомогу, не допускаючи важких ускладнень. 3 цією метою тварин оглядають і виявляють особин з ознаками кульгавості, ускладненими рухами, травмами.

Таким чином, під час лікування свиней із патологією кінцівок слід зменшити біль, відновити їх повноцінну рухову активність, зберегти рівень споживання та засвоєння корму на належному рівні.

тельных средств / [К. О. Попов, Е. Н. Глазьев и др.] // Перспективное свиноводство : теория и практика. - М., 2013. - №3. - С. 27-30.

8. Рыжаков A. B. Травматизм в промышленном свиноводстве: лечение и профилактика / А. В. Рыжаков, В. И. Евдокимова. - Вологда, 2009. - 221 c.

9. Garcia M. C. et al. Effect of gram-negative bacterial endotoxin, oxytocin and dexamethasone on lactation in sows. Proceedings of the IPVS Congress / M. C. et al Garcia. - 1980. - P. 67.

10. Nielsen E. O. et al. Mycoplasma hyosynoviae arthritis in grower-finisher pigs / E. O. et a 1 Nielsen // Journal of Veterinary Medicine. - Series A. - 2001. P. 475-486.

11. Sarel van Amstel et al. Claw horn growth and wear rates, toe length, and claw size in commercial pigs : A pilot study / Amstel et al van Sarel // Journal of Swine Health and Production. - Vol. 18, №5. 2010. - P. 239-243. 